\title{
Immune-based therapy using gamma interferon ingaron in the treatment of HIVIAIDS patients with active pulmonary tuberculosis (PTB) not previously highly active antiretroviral therapy (HAART)
} Auwal Yola*1, Tamara Sologub1, Vitaly Nechaev ${ }^{1}$ and Alexandr Ivanov²

\author{
Address: ${ }^{1}$ Department of infectious diseases and tropical medicine, St. Petersburg Medical Academy, St. Petersburg 191144, Russia and \\ 2Department of Phthisiopulmonology, St. Petersburg Medical Academy, St. Petersburg 191144, Russia \\ Email: Auwal Yola* - auwalyola@yahoo.com \\ * Corresponding author
}

from 2006 International Meeting of The Institute of Human Virology

Baltimore, USA. 17-2I November, 2006

Published: 21 December 2006

Retrovirology 2006, 3(Suppl I):S38 doi:I0.1 I86/1742-4690-3-SI-S38

(C) 2006 Yola et al; licensee BioMed Central Ltd.

\begin{abstract}
Background
Interferon gamma is a licensed product for treating certain immune deficiency diseases, but its use in people with HIV is experimental. IFN- is normally made by CD4 Tcells - the cells which are depleted in people with AIDS and it has antineoplastic effects and antiviral activity mediated by immunomodulatory effects. At a cellular level these include macrophage activation, stimulation of antigen presentation through class I and class II major histocompatibility complex molecules, regulation of leukocyte-endothelium interaction, and effects on cell proliferation and apoptosis. It is therefore theorized that giving HIV-positive people co-infected with TB supplementary injections of interferon gamma may help boost their immune response.
\end{abstract}

\section{Objective}

To obtain preliminary information on the safety, immunologic and virologic effects of IFN-gamma in adults coinfected with HIV and TB with immune reserve (CD4Tcell count above 350 cells $/ \mathrm{ml}$ ) on TB medication but not on antiretroviral therapy.

\section{Materials and methods}

51 HIV-infected persons newly diagnosed with active PTB were recruited in the special HIV and TB unit of the second city tuberculosis hospital in Saint Petersburg, Russia into an observational, prospective study between March and
December 2005. All the patients had a median CD4 cell count of above 350 cells/ml and were not previously on HAART. 21 patients $(41.2 \%)$, apart from standard TB medication also received interferon gamma $(\gamma$-IFN $)$ injection (Ingaron) at a dose of 500000 i.u. subcutaneously three times weekly for eight weeks, while the rest 30 $(48.8 \%)$ received similar TB treatment plus placebo. They were assessed clinically weekly, while laboratory investigations were conducted at the initiation of therapy and at weeks 4 and 8.

\section{Results}

Interim assessment of the outcome of TB treatment at 8 weeks of follow up showed a remarkable improvement of clinical conditions and immunologic responses of the patients receiving gamma interferon (Ingaron) as against those in the control group. In general, $\gamma$-IFN therapy was well tolerated. The major adverse event thought to be possibly $\gamma$-IFN associated was low grade fever. Increase in CD4+ lymphocyte counts and decrease in plasma HIV RNA concentrations were observed in the study group. CD4+ increased from $656.2 \pm 41.3$ to $728.4 \pm 74.7$ cells/ $\mathrm{ml}(\mathrm{p}>0.05)$ (table 1) while plasma RNA became undetectable in 11 patients in the study group as against nil in the control group. 


\section{Conclusion}

Gamma interferon therapy in patients co-infected with HIV and tuberculosis receiving TB medications is safe, improves clinical outcome and enhances host defense mechanism. Larger studies will be needed to assess the drug's long term clinical efficacy in the treatment of HIVassociated complications such as PTB.

Publish with Bio Med Central and every scientist can read your work free of charge

"BioMed Central will be the most significant development for disseminating the results of biomedical research in our lifetime. " Sir Paul Nurse, Cancer Research UK

Your research papers will be:

- available free of charge to the entire biomedical community

- peer reviewed and published immediately upon acceptance

- cited in PubMed and archived on PubMed Central

- yours - you keep the copyright 